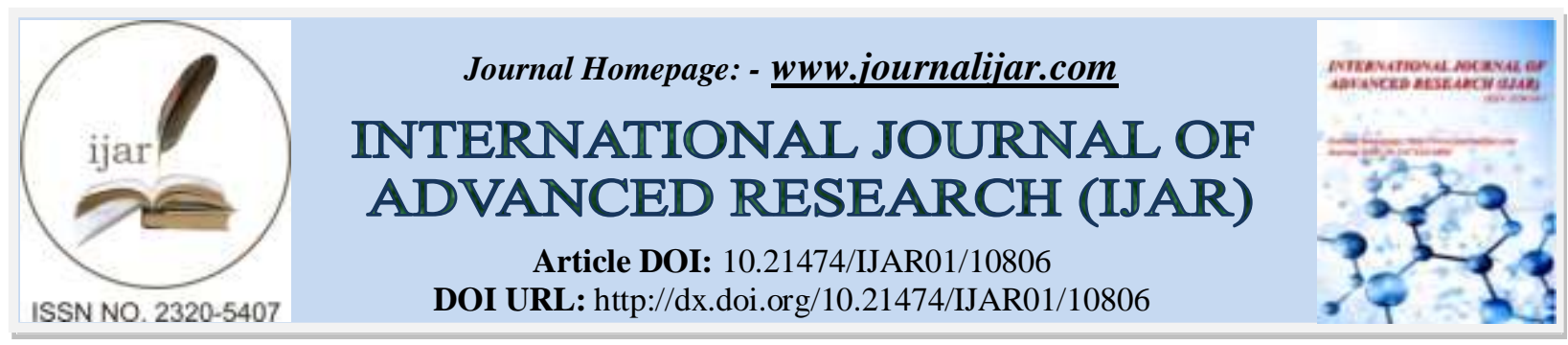

RESEARCH ARTICLE

\title{
ATTITUDE OF PHYSICAL EDUCATION TEACHERS TOWARDS INCLUSIVE EDUCATION IN SRINAGAR DISTRICT OF JAMMU AND KASHMIR (INDIA)
}

\begin{abstract}
Mohd Iqbal Dar
Department of Physical Education, Shri Venkateshwara University.

\section{Manuscript Info}

Manuscript History

Received: 10 February 2020

Final Accepted: 12 March 2020

Published: April 2020

Abstract

The purpose of this study was to investigate attitude Physical education Teachers towards inclusive education in Srinagar district of Jammu and Kashmir, and the factors that influenced such attitudes. Qualitative research was used to gather information from all general education and special education teachers. The sample consisted of 30 teachers at 5 schools. The results of this study showed that teacher's attitudes were strongly influenced by the nature and physical condition of the students.
\end{abstract}

Copy Right, IJAR, 2020,. All rights reserved.

\section{Introduction:-}

Attitude of teachers towards inclusion vary across the education field. Numerous studies have involved teachers' attitudes towards inclusion, in the review below some of the studies referred to have used the term integration or mainstreaming, while others have used the term inclusion. In spite of using different terminology, they all seem to refer to a situation in which a class, a school, or an educational system tries to meet the needs of students with special needs. In this study, the term inclusion is used. An attitude may include cognitive, effective and behavioural components.

The purpose of this study was to explore teachers' attitudes towards inclusive education in Srinagar District of Jammu and Kashmir. The result of this study can be used as a guideline to enhance special education services in a developing country, like IndiaAs mentioned earlier, numerous studies have involved teachers' attitudes towards inclusion and the results vary. The majority of the teachers surveyed had strong negative feelings about inclusion. They felt that the decision makers were out of touch with classroom realties (1991).Scruggs and Mastropieri (1996) in their meta-analysis of 28 survey reports from 1958 - 1995, reported that two thirds of the respondents agreed with the general idea of integration, and a little more than half of them expressed a willingness to teach students with special educational needs in their classrooms. Another study by Vaughn, et al. (1996) examined special education teachers' perceptions of inclusion using focused group interviews. The majority of these teachers, who were currently participating in inclusive programs, had strong negative feelings about inclusion. The teachers identified several factors that would affect the success of inclusion, such as class size, inadequate resources and lack of adequate training.

\section{The present study:}

The purpose of this study is to explore teachers' attitudes towards inclusive education in Srinagar district of Jammu and Kashmir and to gain more knowledge about the factors that may influence the implementation of inclusive practices in a school system in the making. The results of this study can be used as a guideline to enhance special education services in a developing country like India. The research questions were: 
1. Which factors influence teachers' opinions about inclusion?

2. What are the teachers' opinions about inclusion of students with special education needs?

\section{Methodology:- \\ Participants:}

The participants were teachers who had experience with teaching students with special educational needs in public and special schools. The selected schools have followed following criteria:

1. The school should have students with special education in regular classes,

2. The study should include an equal distribution of rural and urban schools.

The school sample consisted of 30 teachers (20 female and 10 male) at seven schools. The procedure for the selection of schools did not aim at recruiting a representative sample of schools, but rather a sample of schools with teachers who are willing to share their opinions with the researchers about inclusion and their experiences regarding students with special needs. This may have resulted in a skewed sample of teachers. It is worth mention that the number of schools and the number of teachers participating in this study were low, and thus the results are an inadequate basis for generalization.

\section{Procedure:}

Preparations for the study involved obtaining permission from the local authorities in the Government and from the principals of the seven schools. The information collected separately in one school at a time, after school hours, with the teachers gathered in a group.

\section{Results:-}

Opinions about inclusion and factors associated with teachers' opinions : 20 out of the 30 teachers were of the opinion that students with disabilities or special needs should have a chance to attend public schools, a closer inspection of the data indicated that several factors might be associated with the participants' opinions towards inclusion, they will be discussed below.

Nature of disability: Twenty-three of the teachers mentioned that students with specific disabilities should be included. The most frequently mentioned were students with physical disabilities, mentioned by 18 of the 30 participants. Students with sensory disabilities were rarely mentioned; 12 of the participants students with visual impairments. The students considered least includable were the students with mental retardation and behaviour problems that may affect reading, writing and arithmetic. Seven teachers specifically mentioned that students with mental retardation should not be included in public schools.

\section{Number of subjects taught:}

The participants could be divided into four groups according to the number of subjects they taught. 12 teachers taught one subject, 8 teachers taught two subjects, 6 teachers taught three or four subjects, and 4 teachers taught all subjects that were offered to the students. The data suggest that the acceptance of inclusion increased as the teacher taught more subjects.

\section{Gender of the teachers:}

There was little difference between the opinions of female teachers and male teachers. The data suggest that female teachers were more positive than male teachers were.

\section{Training :}

The participants mentioned five topics of future training. The topic with highest priority was parent-teacher collaboration. The next four preferred topics of concerned differentiation in the classroom and ways of organizing special needs education such as preparing individual education plans, individual instructional plans and behaviour modification plans and curriculum adaptations.

\section{Conclusion:-}

The present study investigated the opinions of selected teachers in Srinagar District of Jammu and Kashmir, who had experience with students with special needs in regular schools. Due to the sampling procedure of the study and limitations of the instrument, the result must be interpreted with caution. 
Teachers' beliefs and acceptance of the policy and philosophy of inclusive education are significant predictors of the degree to which they carry out inclusive practices. The affective and behavioural components pf teachers' attitudes towards inclusion should be subjective to future studies. In addition, factors that in this study have been identified as potentially influencing the opinions of the teachers, such as the nature and severity of their students' disabilities, teachers' previous experience with students with disabilities and contextual factors related to the individual schools, should be included in future investigations.

A majority of the teachers who participated in this study expressed a need for changes in public schools in order to meet the needs of students with disabilities, and they particularly emphasized the importance of increased knowledge and skills that could empower them as professionals. For the purposes of future initial and in-service training for teachers, it may be of interest to know to what extent other teachers in Srinagar district of Jammu and Kashmir share such priorities.

\section{References:-}

1. Algozzine B., and Yesseldyke, J.,(1981).Special education services for normal children:Better safe than sorry? Exceptional Children,48,238-243.

2. Allen, K.E., (1980). Mainstreaming in early childhood education. Albany,New York: Delmar Publishing.

3. Allen, K.E., and Schwartz (1996). The Exceptional Child: inclusion in early childhood education. $3^{\text {rd }}$ Edition, Singapore:Delmar Publishers.

4. Barrage,N., (1983). Visual handicaps and learning. Austin, TX: Exceptional Resources.

5. Dash,M.,(2000):Education of Exceptional Children, Delhi, Atlantic Publishers.

6. Department of Education (2003). Inclusive Education Scheme (Draft). New Delhi : MHRD,GOI.

7. Fain, G.S., (1986). Leisure: A moral Imperative.Mental Retardation, 24,261-262.

8. Hewett, F.M., and Forness, S.R., (1984), Education of Exceptional Children, London,Allyn\& Bacon.

9. Kirk, S., (1962), Educating Exceptional Children, Boston, Haughton Mifflin.

10. Kough, J., and Dehann, R.F.,(1955), Identifying Children Who Need Help, in teacher's Guidance Handbook-1, Science Research Association, Chicago.

11. Ministry of Human Resource Development (1992). Revised Programme of Action (1992). New Delhi:GOI.

12. NCTE Bulletin (1991), Volume III, No.2-4, NCTE,New Delhi.

13. Panda, K.C., (1997), "Education of Exceptional Children" New Delhi, VikasPublishing House Pvt. Ltd.

14. Project Integrated Education for the Disabled (1987), NCERT, New Delhi.

15. Suran B.S., and Rizzo, J.V.,(1979),Special Children :An integrative approach, England, Scott, Foresman\& Company.

16. The Mental Health Act (1987): Government of India, New Delhi. Wallace, G., \& Kauffman, J.M., (1986). Teaching children with learning problems $\left(3^{\text {rd }}\right.$ ed.) Columbus, OH:Merrill.

17. Wood,J.W., (1989), Mainstreaming:A Practical Approach for Teachers. Columbus,OH:Merrill.

18. Ysseldyke, J.E., and Algozzine,Bob, (1988), Special Education, New Delhi,Kanishka Publishers. 